\title{
Selected Methods of Intervention Suitable for Work Social Educator with Children at Risk of Social Exclusion
}

\author{
Helena Skarupská
}

\section{Contact to author}

Tomas Bata University in Zlín, Faculty of Humanities, nám. T. G. Masaryka 5555, 76001 Zlín

skarupska@fhs.utb.cz

\section{Kontakt na autora}

Univerzita Tomáše Bati ve Zlíně, Fakulta humanitních studií, nám. T. G. Masaryka 5555, 76001 Zlín skarupska@fhs.utb.cz

Copyright (C) 2016 by authors and publisher TBU in Zlín. This work is licensed under the Creative Commons Attribution International License (CC BY).

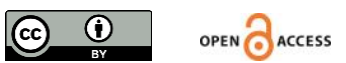

\begin{abstract}
The study deals with the possibilities of the use of certain methods, which have their origins in social work and are also useful in the work of social educator working in socially exluded localites. The study is based on the concept of social educator as a separate profession and highlights one of the ways in which social workers should act. Deliberately focuses on the methods of work as a fundamental instrument profession. Socially excluded localities, unfortunately, become an integral part of Czech society. When working with the residents to create multidisciplinary teams that include social educator who acts as a bridge between educational establishments, family and welfare authorities. In the paper, we introduce a few selected methods, which are suitable for the job and that could broaden the skills and hence the competence of social educator, including the definition of social exclusion and its associated culture of poverty as a specific phenomenon.
\end{abstract}

Keywords: social pedagogue, social exclusion, child at risk, method, intervention, culture of poverty

\section{Vybrané metody intervence vhodné pro práci sociálního pedagoga s dětmi ohroženými sociálním vyloučením}

\begin{abstract}
Abstrakt: Studie se zabývá možnostmi využití některých metod, které mají původ v sociální práci a jsou využitelné $\mathrm{i} v$ činnosti sociálního pedagoga působícím v sociálně vyloučených lokalitách. Studie vychází z konceptu sociálního pedagoga jako samostatné profese a poukazuje na jednu z možností, kde by sociální pracovník měl působit. Cíleně se zaměřuje na metody práce jako základního nástroje profese. Sociálně vyloučené lokality se bohužel staly nedílnou součástí české společnosti. Při práci s jejich obyvateli se vytvářejí multidisciplinární týmy, jejichž součástí je i sociální pedagog, který zde působí jako most mezi školskými zařízeními, rodinou a orgány sociálně právní ochrany. Ve stati představíme několik vybraných metod, jež jsou pro tuto práci vhodné a jež by mohly rozšírit dovednosti a tím i kompetence sociálního pedagoga, včetně definování sociálního vyloučení a s ním spojené kultury chudoby jako specifického jevu.
\end{abstract}

Klíčová slova: sociální pedagog, sociální vyloučení, ohrožené dítě, metoda, intervence, kultura chudoby 
Skarupská / Selected methods of intervention suitable for work social educator with children...

\section{Introduction}

In this study, focusing on description of selected methods/approaches inspired by social work which are suitable for the intervention of a social educator as a member of the multidisciplinary team working with children at risk of social exclusion. The social educator has not had a clear legislative and thus competent anchoring in the system of helping professions even if social pedagogy in the Czech Republic has been developing intensively for a quarter of century by which his position in a multidisciplinary team becomes difficult. It follows that the choice of procedures, ways and methods of intervention is not always completely clear to everybody.

The first part of this article is devoted to defining differences between the social worker and social educator. It very briefly describes how different these two professions are and what is the most common conception of a social educator in contemporary Czech discourse.

The fundamental part of the article is focused on methods/approaches, specific intervention approaches $^{1}$ that are not uniform in the theory of social pedagogy. Kraus (2008) belongs to the authors who are engaged in social pedagogy methods. He works with the methods of social and educational activities. ${ }^{2}$ His approach to the methods is based on the fact that the social educator will do educational work - that he was useful as a leisure time educator, tutor or teaching assistant. These methods of social and educational activities are needed but their application within the multidisciplinary team in working with endangered children in socially excluded areas, is not sufficient.

Another author, more properly speaking, a woman author - Bakošová devotes to the issue of methods in the theory of social pedagogy. The author (2008) attempted to make her own classification of methods of social pedagogy by linking educational methods with the methods of social work where only some approaches were chosen, as for example compensation of inappropriate stimuli, strengthening own competence, offering of incentives resulting from individual needs, planning a positive perspective and support for orientation to self-realization, as well as methods of counseling and prevention, including consultation, supervision and intervention. Her description of methods is very brief, mostly providing information, it is more concerned with brief characteristics than with the own process analysis.

Already here in the introduction, it is necessary to define terminology of a method and an access. In most sciences a method is considered as a way leading to a goal, that is the procedure. In social work three basic methods of work were historically developed - work with individuals, groups and community. Own intervention is called an approach that is based on theories of social work. There already is a visible difference between social work and social pedagogy because in pedagogy procedures are called methods.

The aim of this study is based on a theoretical analysis of the culture of poverty as a phenomenon accompanying social exclusion and thus to submit several approaches in social work, including their description and appropriate use of work when working with endangered children in socially excluded localities. The social educator can now work according to them and thus extend his practical skills of socially educational activity methods.

1 Intervention is interpreted as professional interference in the social situation of an individual or a group, or a community exercised in their favour.

2 Kraus (2008) describes a method of organizing, group work, situational, staging, regime, animation and mediation. 
Skarupská / Selected methods of intervention suitable for work social educator with children...

\section{Social educator is not social worker}

Before we begin the selection and description of our appropriate methods, we must first focus on defining of a social educator. As was written in the introduction, a social educator does not have a clear legislative definition in the Czech Republic.

Currently, the graduate of social pedagogy, according to Act No. 563/2004 Coll. (2004) can act as a tutor, a teacher responsible for leisure time activities and a teaching assistant. All these teaching professions have a description of activities and determined competence. They also have their own degree courses that prepare for these specific positions. The social educator is not educated to be only a tutor, teaching assistant or a teacher of leisure time activities. His academic field is different. He specializes in issues of social phenomena related to education - the education in the broadest sense.

The social educator can also perform, according to Act No. 108/2006 Coll. (2006) work of a social worker. Even here, however, we have specialized fields of educating social workers directly. Is social pedagogy considered to be a social work? Certainly not, although the focus is very similar. The definition of Social Work approved by the International Federation of Social Workers (IFSW, 2015) says that "social work is a practical profession and academic discipline that promotes social change and development, social cohesion, empowerment and liberation of people. Principles of social justice, human rights, collective responsibility and respect for diversity are fundamental to social work. Supported by theories of social work, social sciences and humanities as well as local knowledge, social work involves people and structures to solving problems and improving welfare." According to this definition, social workers are bearers of changes in society and in the lives of individuals, families and communities. Thus their focus is very similar to a social educator. He is also a bearer of changes. In contrast to the social worker, who uses social attitudes while working with a client or clients, the social educator is primarily a teacher, i.e. the one who works in the field of education and choses educational approaches. Laca (2011) perceives a social educator as a specialist, who helps children, youth, adults and parents in situations of balancing socialization deficit. He seeks possibilities for a better quality of life through prevention, counseling or education.

Who is a social educator? A social educator is located on the border among pedagogy - educational ciences and social work. The main difference between these two professions should be competence and based on them the tools that are used to achieve the goal. Another difference is in the position in which he stands in the organization. And the position is based on the concept of a social educator.

Regarding the position of the institution where the two professions meet, the social worker is intended for direct work with clients to assess the situation ${ }^{3}$ and determine the therapy, plan, what will happen next with the client. The social educator, like special education teacher or school psychologist in direct work with a client or a pupil performs a specific therapy.

The first concept of a social educator, which is quite widespread in the Czech Republic, is a social educator as a manager of social problems. This concept is report by the authors Andrysová and Martincová (2014, p. 45), who say "that the social educator organizes and manages the educational process at a professional level and he influences the subject at two levels - integration and development." Thus they adopt the definition of the profession, as it is accepted by Kraus (2008).

Other concept is offered by the workers of Faculty of Arts, Masaryk University. In their conception the social educator is perceived primarily as a counselor, which corresponds to the field of specialization offered by the study - Social Education and Counselling. Social educator as a counselor who would realize educational counseling, prevention of risky behaviour and career counseling at one position at schools and school facilities, is already currently very necessary specialization of teaching staff. Unfortunately, the current state of law does not allow it, it is a pity to everyone

3 Assessing is a term replacing the term of diagnosis, diagnose that was used in the past. 
Skarupská / Selected methods of intervention suitable for work social educator with children...

- teachers, pupils, parents. While abroad, the school counselor is a normal specialization for several decades, for us it is still a tendency to replace this place by a school psychologist. However, the psychologist is not educated in the issues of education on one side and on social issues on the other, which is now involved in a range of school issues.

The author of this article further defines the social educator as a therapist. It is based here on the definition of social therapy "as a specific kind of professional intervention aiming at achieving, by a direct and indirect effect, desired changes in client behaviour and in his social environment, to solve the situation, which directly threatens the client and prevent risky behaviours and conditions that may support its development" (Zakouřilová, 2014, p. 15). The social educator uses methods of socioeducational action to remedy, remove, recover a social problem with the active participation of the client. He may do so himself within his work in various types of equipment, or as a team member. This concept is also directed to this study. As stated in the introduction to this paper, a social educator should be a member of a multidisciplinary team that is committed to improving the situation of children in socially excluded localities, i.e., to correction - therapy.

Professional work and assistance in these areas is only effective when the team is working well and in accordance. The team mostly consists of a community worker who manages the team, streetworkers, staff of the Social and Legal Protection Children, Labour office workers, curators, possibly psychologists and lawyers in cooperation with schools, governments and businesses. In this team there is an irreplaceable position for a social educator who should be primarily a mediator among school, family and staff of social and legal protection of children. Therefore, such worker must be - a social educator - equipped with appropriate methodological approaches to choose the appropriate form of intervention.

\section{Endangered child and social exclusion}

Before I get to own methods of intervention, it is necessary to define who is an endangered child, a child in a socially excluded locality and what the socially excluded locality is.

In the Czech Republic there is no single definition of an endangered child. We find this concept in legal documents in the early 90s of the last century, when in 1990 the World Declaration on the Survival of children, their protection and development was adopted by the United Nations. Article 22 of the World Declaration (1990) defines the terms that apply to child endangerment. For an endangered child is thus considered a child - "an orphan, street child, a child of refugees, displaced persons, victims of wars, natural and man-made disasters, children of migrant workers or children living in other socially disadvantaged groups, working children, children and young people trapped in prostitution, sexual abuse and other forms of exploitation, disabled children, adolescent offenders, victims of apartheid and foreign occupation."

The problem of inconsistent terminology is warned by the materials of the Ministry of Labour and Social Affairs such as Proposed measures to transform and unify the system of care for endangered children - basic principles of 2009. Here an endangered child (2009a, p. 3) is defined "as a child who does not meet or there is an assumption of unfulfilled basic biological, psychological, emotional, social and spiritual needs (need for stimulation, order, love, safety, social and societal recognition, open, shared future). Another role is played by the social determinants of health and child rights. We can say that every child is potentially at risk, more or less. Border is not possible to be determined strictly, there are many factor threats as well as their intensity and development. Attention must be focused on potential risks."

The National Action Plan to transform and unify the system of care for endangered children for the period from 2009 to 2011 defines the basic concepts on the basis of the multisectoral nature of the entire document. For an endangered child (2009b, p. 5) is considered "a child whose basic needs are 
Skarupská / Selected methods of intervention suitable for work social educator with children...

not met adequately and is threatened by risky behaviour." This definition is short but the more concise and in this study will draw from it.

The second term, that stands in the title of this chapter and which is to be defined before we proceed to the choice of methods of intervention, is a social exclusion. Social exclusion is a term that first appeared in the 70s in France for individuals or groups of people who were excluded from the system of state social security. The founder of the concept is considered a French politician René Lenoir, who dealt with the concept in his book Les exclus: Un Français sur dix from 1974. The concept was gradually taken over by the European Community in the 80 s of the 20th century and began replacing the term "poverty". Current literature offers many definitions of the term. The Czech space is most often used by the general definition based on the documents of the European Union (2001), where social exclusion is a process which leads to crowding of people on the margins of society and thay are limited to access to resources. It follows the fact that the socially excluded are difficult or limited to access to social institutions, they are not represented in political organizations, they can not participate in their rights by representation in governing bodies, have significant limitations on the labour market and thus they become long-term unemployed and unemployable.

Social exclusion is not only poverty, as it is sometimes inaccurately reported, as has been observed by a British sociologist Levitas (2003). Apart from poverty, she classifies unemployment and a specific behaviour with features of pathology - people without morals as a part of social exclusion. For Mareš (2006), this is not a complete list and he adds to these phenomena dimension of diversity - cultural, religious, linguistic. Here we can see a different view of cultural exclusion feature. Levitas incorporates it into the underclass, to people without morals, people of other subcultures while Mareš can see it as a separate phenomenon. All these phenomena are a part of current discourses on social exclusion in Europe.

Czech specific perceptions of social exclusion during the 90s of the 20th century, almost the entire first decade of the 21st century is narrowing to only one ethnic group and Roma. At that time social exclusion was viewed as a problem of the Roma ethnic group and its inability to integrate into mainstream society. The change was brought by the crisis of 2008-2013, which affected a large part of the population of the Czech Republic, and as shown by analysis of socially excluded localities, 2014 (GAC spol s.r.o, 2015), the Czech Republic increased in these areas without Roma. According to this analysis about 95 to 115 thousand inhabitants of the Czech Republic lived in socially excluded localities in 2014, in 297 municipalities with 606 locations and 700 dormitories, where a substantial part of the population lives ${ }^{4}$. Number of children is alarming. "A total of 22 percent of all pupils growing up in socially excluded localities are trained in a highly ethnically homogeneous schools. In absolute terms, this could mean a total of 3.000 to 3.500 pupils, "as presented by the authors of the Analyzes (GAC spol s.r.o., 2015, p. 10).

Because poverty is a central concept of social exclusion, let us look at it more closely now. Poverty is a phenomenon that has accompanied mankind since the time when a person became aware of social differentiation. From this point poverty is considered as a source of social problems. Defining of poverty is very diverse and therefore there is a large number of different definitions of poverty, which differ from each other by different views of this phenomenon. The concept of lack is the basis of all definitions. Most often, poverty is defined as a situation in which an individual or a social group can not meet the most urgent needs of its own funds (Dohnalová, 2011). When creating definitions two approaches are usually considered. The first approach is objective and focuses on the determination of universal human needs and their degree of fulfillment. Second, the relative approach shows that poverty must be seen in historical and sociocultural contexts in particular. Objective approach establishes peace, threshold, border or poverty line, which is the lowest level of income, which is still considered to be sufficient in a particular country.

4 In the Czech Republic was to 2015, 1 January 10261791 inhabitants and 6259 municipalities (MVČR, 2015). 
Skarupská / Selected methods of intervention suitable for work social educator with children...

Poverty is seen as a source of human problems, different authors were dealing with the causes of poverty and the characteristics of people living in poverty both in the past and in the present. A view of the poor again has two levels. One group of authors sees the poor as independent, sincere, honest, happy and divinely ordained, the second group is perceived as incompetent, lazy, dirty, evil, who can blame themselves for a life in poverty. These two levels affect the forms and procedures for dealing with poverty. Supporters of the first plane advise to leave the solution of the problem on their own people because they consider them to be motivated, capable and able. Conversely, the second group recommends setting programs to combat poverty in the form of direct control of specific public authorities.

On this topic, whether poverty is the result of the inability or failure, a scientific study by an international team of behavioral economists was published in the 341st issue of the journal Science in 2013. The study is called Poverty Impedes Cognitive Function and focuses on measuring cognitive functions, especially the intelligence, in the groups of people who are experiencing a period of poverty. The study authors Mani, Mullainathan, Shafir and $\operatorname{Zhao}^{5}(2013$, p. 980) emphasize, that "the data reported here suggest a different perspective on poverty: Being poor means coping not just with a shortfall of money, but also with a concurrent shortfall of cognitive resources. The poor, in this view, are less capable not because of inherent traits, but because the very context of poverty imposes load and impedes cognitive capacity. The findings, in other words, are not about poor people, but about any people who find themselves poor." In the next section of the text the authors draw attention to the results regarding the measurement of intelligence. As a result of becoming poor, differences in intelligence reached to 13 points. It follows that intelligence is not a fixed constant, but is significantly affected by socio-cultural influences. The paragraph ends with the sentence (2013, p. 980): "These sizable magnitudes suggest the cognitive impact of poverty could have large real consequences."

The American anthropologist Lewis ${ }^{6}$ points to the need to distinguish between the concepts of poverty and a culture of poverty. Already in the 50s of the 20th century, he studied behaviour in poor areas of Mexico, then in Puerto Rico and New York. In Social Sciences he brings the term culture of poverty, which clearly defines the article called The Culture of Poverty, published in the 4th issue of the journal American from October 1966. The term culture of poverty is used as "a specific conceptual model that describes a subculture of Western society, which has its own structure, internal logic and their own way of life, passed in family lines from generation to generation" (Lewis, 1966, p. 19). Lewis in his article identified 70 characters that characterize the culture of poverty. These characters are summarized into four dimensions of the system. The first is the relationship between subculture and mainstream society, second is nature of slum communities, the third character of the family (sexual life begins very early, marriages are rare, most couples live only in partnership, family centers around mother and mother's family, the relationship of mothers to children is rational, with a minimum of love and protection, childhood is very short), and the fourth is formed by positions,values and structure of the character of an individual.

Another typical feature of the culture of poverty is living in the present. People do not plan, live in the moment, if they receive some benefits, which are paid for a month, so they consume them immediately and according to what is interesting for them at the moment. There is no motivation to change, they are dependent on the system. Language is poor, they do not understand to many

5 Anandi Mani is a professor of economics at the University in Warwick and she devotes to behavioral ekonomics and a culture of poverty. Sendhil Mullainathan, a professor of economics of Harvard University, dealing with behavioral economics and poverty. Eldar Shafir, professor of Princeton University in the cognitive sciences, with a focus on behavioral decision making and policy and Jiaying Zhao, associate professor of psychology, University of British Columbia, with a focus on behavioral science.

6 Oscar Lewis (1914-1970) originally studied history, gained a doctorate in anthropology at the Columbia University in research focusing on the lives of peasant families and neighborhoods - slums (see http://whatwhen-how.com/social-sciences/lewis-oscar-social-science). 
Skarupská / Selected methods of intervention suitable for work social educator with children...

concepts, they have poor verbal skills. "These people only know their surroundings and their own way of life, their outlook is at a provincial and local level, with little knowledge of history.They usually do not have knowledge, vision or ideology to see the similarities among their problems and their counterparts elsewhere in the world. They have no conscious of class, although they are really sensitive on symbols of their condition" (Lewis, 1966, p. 23). An explanation of these attitudes, structures and values is now clearer. As found by the authors of the study Poverty impedes cognitive functions, which is written above, it is the underdeveloped cognitive processe that reduces visibility and overall perception of those persons.

Lewis was very often criticized for his concept of the culture of poverty. Opponents accused him with psychological schemas as machismo, unclear sexual identification or inclination towards high number of psychopathological behaviour among people in a culture of poverty. Furthermore, he was criticized for his suggestions. Lewis was socially democratically oriented, therefore he thought that introduction of a state system of social protection in the form of benefits will solve poverty (cf. Smelser \& Baltes, 2001, pp. 11904-11907). A very broad setting of social assistance system is currently a cause of living in a culture of poverty and is making social exclusion.

In 1984 the issue of state guaranteed benefits was highlighted by Murray ${ }^{7}$ in his book Losing Ground (published in Czech Republic under the title Too much good, 1998), which analyzes 30 years of social policy in the USA from 1950 to 1980 and concludes that it was the generosity of government in social policy and it is the cause of the stagnating poor in American society. According to him, the poor lost not only the motivation to do something about their poverty, but also self-esteem. "Governmental social policy helps to establish the rules of the game... When population is more endangered and the less number of independent sources it has, the stronger effect of the rules of the game is, applied from above. The most convincing explanation for the significant change in the fortunes of the poor is that they continue to respond to the world as before, i.e. in the form as they found it, while we meant non-poor and non-concessionary - we have changed the rules of the game of their world. Not the rule of our world, only of theirs. The first of these new rules was that the poor have begun to behave in a short term in a way that was disastrous in the long term. The second effect was to camouflage these long-term losses - subsidizing irreparable mistakes. We have tried to give more to the poor, and instead we have increased their number. We have tried to remove the obstacles on the way out of poverty and thus inadvertently we have built a poverty trap" (Murray, 1998, pp. 21-22). Murray, on the contrary, proposed reduction in social benefits, their abolition at the state level and transfer to the local level, closer to the beneficiaries and to assess their real claim on the basis of need. His proposals were also highly criticized, especially from the social democratic positions. The crisis of the welfare state in many respects, however, gives the author the truth, it turns out that living on social benefits is a poverty trap and as Lewis $(1966$, p. 21) says "when the culture of poverty occurs, it tends to maintain."

Lewis's concept of the culture of poverty and social exclusion concept begin to fade together in the late 20th century, at the time when, according to some experts, for example Toušek (2007, p. 14) is "happening that ways of adapting to the conditions of social exclusion are so specific and comprehensive that they set up their own subculture. According to the same author the existence of this subculture may be the actual cause of social exclusion."

Based on these findings, I would like to make a summary that social excluded is a specific subculture of a developed society, characterized by a culture of poverty manifested in the dimensions of economic, cultural and social, symbolic, political and spatial exclusion.

The economic dimension of social exclusion is given by unemployment, indebtedness, usury and living on benefits. Cultural, social and symbolic are reflected in norms, rituals, language, attitudes,

7 Charles Murray (1943) is an American conservative political scientist, who became famous mainly as an coauthor of the controversial book The Bell Curve from 1994. Much of his interest is the welfare state, intelligence and education policy (see http://www.aei.org/book/education/real-education). 
values, family structure and identity. The political dimension is given by a lack of interest in public affairs and negativity to everything official, in conformity, represented by the state or self-governing powers. Dimension of spacial exclusion is given by a creation of excluded localities in the form of ghettos or slums. All these dimensions are intertwined with one another and their separation is artificial, serving only as an auxiliary tool to describe.

The above text makes clear that every child who lives in such location is a child at risk, because its basic needs are not met adequately and is threatened by risky behaviour.

Unfortunately, the number of children in the Czech Republic amounts to several thousands. The number of 606 excluded localities in 2014 is a high number, to which must be paid sufficient attention. Therefore there is a need for the creation of multidisciplinary teams that are working in socially excluded areas and trying to change the conditions of life of these people. Targeted focus on children at risk can help to ensure that at least they emerged from these locations and integrated with mainstream society.

Therefore, every worker of a team should have in mind the specifics of socially excluded groups and sites that concern to children, and their summary follows:

- They live in the present, do not know long-term planning, the future is something so remote that they do not work with it.

- Cognitive functions are limited, the child is unable to use all the cognitive potential due to its environment; Language is simple, children often do not understand the words, which are used by a member of the majority.

- If a language is different, thinking is different, too - is focused on the present, opinions are simple and practical, leading to survival, without insight into a broader context.

- Education is underestimated, has no value for them.

- The family is characterized by weak relation links.

- Relationship to mainstream society and particularly its norms and values is negative, often completely opposite.

- $\quad$ They are not interested in participating in public.

- They expect that the state or municipality will ensure them, they do not understand that they themselves should be able to take care of themselves, be active in a legal search of livelihood.

- $\quad$ They assume the way of life from generations of parents and consider it to be natural.

Presented characteristics are brief and incomplete list of different thinking and behaviour in children and adults living in social exclusion but it is considered to be essential and necessary to understand the differences and also important for the correct selection of interventions and at the same time the methods of working with these children and their families.

\section{Selected methods of intervention at work of a social educator with an endangered child in a socially excluded localities}

Because social work as a discipline has been concentrating on the issue of solving poverty and social exclusion for several decades, it is appropriate for a social educator to find inspiration for using methods of social intervention just in it.

First, however, let's have a look at the methods that social educators learn the most often during preparation for their profession. They are primarily educational methods. The pedagogical textbooks contain these methods of educational work - the method of explaining, persuading, asking requirement, repression, advice, pleas, orders, encouragement (stimulation), example (pattern), 
Skarupská / Selected methods of intervention suitable for work social educator with children... $\mid 95$

exercise, reward, punishment regime, cooperation, competition, ritual (cf. Grecmanová et al., 1996; Kraus, 2008). These methods are effective in work of any teacher. However, they are inadequate for quality work of social educators.

Therefore, this chapter of the article extends classification of methods designed by Bakošová (2008), which is based on both the methods of educational influence and the methods used in social work. Unlike the brief characterization of methods I will focus on the detailed description of the possibilities of using them by a social educator working with endangered children from socially excluded localities.

When choosing approaches, the author of the study held the division, as used in social work.

As the first method of social intervention I chose an approach oriented to tasks. Approach is based on the theory of social learning, theory of systems and cognitive theories. For authors are considered Reid and Epstein, who in 1972 formulated a system of a short-term intervention. The basis for this approach is a partnership and strengthening. Navrátil and Matoušek (2013, p. 109) state "that the basis of an approach lies in the idea that the little success develops self-confidence, and that a man would rather accept the tasks of his own choice." The method is based on six stages - preparation, exploration of the issue, agreement on objectives, formulation and implementation of tasks, completion and testing. The individual steps in detail include:

1. Preparation is the legitimacy of the intervention, which is based on cooperation and understanding to the objectives of the intervention.

2. Exploration is clarifying the client's interests, defining and sorting by order of importance.

3. Agreement on objectives is about direction of change and is based on eight categories of problems established by authors and they are:

- Interpersonal conflicts.

- Dissatisfaction of social relations.

- Problems with formal organizations.

- Difficulties in fulfilling roles.

- Problems arising in connection with the social changes.

- $\quad$ Reactive emotional distress.

- Inadequate resources.

- $\quad$ Difficulties with behaviour (behavioral problems). ${ }^{8}$

4. Formulation and implementation of tasks means the frequency of contacts, length of contract and specific tasks.

5. Termination is determined at the outset that the client knows how long it will take cooperation.

6. Testing applies only to a social worker who discovers how successful his intervention was (cf. Navrátil, 2007).

Task oriented approach has great potential of application uses because it can be applied both in the development of mental activities and in training of real activities. Its advantage is that it results in a change, to the strengthening of self-confidence of an individual and groups.

Use of task-oriented approach when working with an endangered child from socially excluded localities, is wide. It can be applied to both the educational sphere and on the change and development of an individual and his family.

8 The exact description of the Encyclopedia of Social Work (Navrátil \& Matoušek et al., 2013, pp. 110-111). 
Skarupská / Selected methods of intervention suitable for work social educator with children...

Because social excluded live in the present, they can not plan future and that it is so remote that it does not motivate them, it is appropriate for the individual educational objectives, when applied in the educational field, to divide them into smaller sections and then further into individual tasks.

For better understanding of a pupil and thus the correct setting of individual tasks, educator can be helped by completing eight categories of problems, as listed in the agreement on objectives.

We must also realize that children have small, almost zero motivation. And here it is appropriate to motivate them to perform tasks which are short and the child can see a rapid result. It is better than to set long-term objectives, such as - if you are successful in elementary school, so you can choose a quality secondary school and your work perspectives will improve. Such motivation is not natural and therefore useless for pupils from socially excluded backgrounds.

If you can make contact with the parents of the child, even here, it is appropriate to show the benefits of education in the present than in the future. Most parents of socially excluded pupils perceive school as a hostile territory, as an institution that belongs to the major society. ${ }^{9}$ An educator can not rely on the fact that parents are willing to work with the child at home, that they will help or check homework. It must also reckon with the fact that it is a big problem for the child to bring to school all devices that are needed for a particular day. A task-oriented approach can help here, too.

This approach can also be used in cases when a volunteer is involved in the educational process who provides tutoring. Then there is a very good agreement between the teacher, volunteer and the pupil's parents, when various tasks and responsibilities of the different actors are set. The agreement should be set, with the cooperation of different actors, by a social educator who acts as an expert and coordinator. The role of a social educator as a member of the multidisciplinary team lies in the fact that he helps the school to find suitable volunteers, ensures contact with voluntary organizations and cooperation among the school, parents and social workers - from communities, terrain, department of social and legal protection of children and curators.

The second method of intervention is the reality therapy, which as a counterweight to the psychoanalytic approach has been created by an American psychiatrist Glasser ${ }^{10}$ in 1960. In 1965 he published a book Reality Therapy, which describes the method. The basis is the principle of reality and responsibility. The aim of this approach is that people are able to evaluate their behaviour as right or wrong in compliance with applicable laws and social standards. People who deviate from the standard, they are unable to meet their basic needs, especially the need for affection and the need for respect - to know that I have value for myself and for others. The purpose of intervention is to focus on working with clients at present and future, not to deal with the past.

In the reality therapy it is necessary to help clients to understand the world realistically and realistically meet their needs. For this it is important for the client to be in personal deep relationship with one or two persons. These relationships are the most important because through them the client gains strength and encouragement to be able to cope with reality. The client has to learn how to correct and appreciate himself. Responsibility is the ability to meet the needs in such a way as not prevent other people in meeting their needs. A responsible person is motivated to make struggle and suffer hardships in order to become self-esteem. Socio-educational activities lead toward greater maturity and responsibility of clients who are inadequately socialized. A social educator must teach a client in a short time what is learned during childhood or adolescence, both in his family and school environment. Reality therapy consists of three complementary techniques:

- $\quad$ Develop a deep personal relationship with the client.

9 Claiming that most parents perceive school as a hostile territory as we find already in the aforementioned Lewis (1966), and Smelser and Baltes (2001).

10 William Glasser (1925-2013), in addition to real estate therapy, he is also an author of Choice Theory, which according to him explains all human behaviour (cf. William Glasser Institute, 2015). 
Skarupská / Selected methods of intervention suitable for work social educator with children...

- $\quad$ Reject such behaviour of a client, which is unrealistic and irresponsible, but in spite accept the client and be involved in his life.

- Gradually teach the client better, more responsible and more mature ways of meeting the needs within the boundaries of reality (cf. Novotná \& Schimmerlingová, 1992).

Procedure of reality therapy can be summarized in the following steps:

1. Participation - here is to create a relationship between the two parties, a worker must be able to gain trust and act upon a client as a natural authority, as a mentor who understands and also gives a clear sense of belonging and acceptance.

2. Evaluation of the current behaviour - it discovers what the client is doing, why he is doing that, if he understands what he does, and a therapist or a worker explains neighborhood response to client behaviour, what are the norms, rules and leads the client to make himself recognize, where his behaviour or conduct is inadequate with thestandard in a given society.

3. Planning of possible behaviour - if, in the form of small steps, a change in client behaviour is planned, with understanding and insight of the client, identification with the necessary change in his behaviour. It is good when the first tasks are scheduled to be successful, it leads to strengthening the client.

4. Commitment to plan - this phase is built on acceptance of the plan of changes in behaviour of the client. It is advisable, if only it is possible, a plan to be drawn up in writing and the therapist and the client sign it.

5. No excuses, no punishment - because it is worked with explaining, acceptance or rejection of the client's behaviour, but not with punishment for bad behaviour or failure to comply with the plan, thus eliminating unnecessary excuses why something is not possible. If the client is not able to keep the plan, he has the option to propose adjustments after agreement with the employee (see William Glasser Institute, 2015).

Reality therapy has been primarily directed to the social rehabilitation of prisoners. It is very close, as well as the first mentioned method, to the cognitive behavioral approaches. In the current social work its use is much broader and can be used where an individual has set no boundaries of his behaviour, he does not know any commonly applied rules of conduct, and he does not recognize conformity.

The author of reality therapy Glasser used this approach in education. Centre of use of this approach lies in the field of education. With respect to that, students from socially excluded backgrounds have different boundaries - what is allowed and what is not, they live in other rules and standards are different and often hardly identifiable with the standards of the majority, reality therapy is very suitable for the change in behaviour.

Social educator explains what is appropriate behaviour, what the rules are and what are the standards that the majority recognizes. He explains everything through step by step techniques and performs feedback or reflection or mirror techniques, and thus he demonstrates his disagreement with the pupils behaviour outside the norm. Because the pupil is usually very well aware of his rights from his home, the teacher has to explain that rights mean also obligations. If the pupil or his parents want to exercise the rights, they must also perform the duties. The basis is made by patience, calm communication and consistency on the part of the teacher. The same techniques can be used to communicate with parents.

Third chosen method of intervention is antioppressive approach. This approach has its origins in the $80 \mathrm{~s}$ and $90 \mathrm{~s}$ of the 20th century in the USA, UK, Germany. It is based on a term oppressive - oppressed. Antioppressive thus means against oppression and it is also used in the sense of antidiscrimination. This approach aims to reduce individual and institutional discrimination based on 
Skarupská / Selected methods of intervention suitable for work social educator with children...

race, gender, disability, social class and sexual orientation, according to the Dictionary of Social Work by Thomas and Pierson (1995).

In 1992 British author Neil Thompson came with antioppressive approach as a uniform model of social work. He identifies three basic requirements of antioppressive approach:

- Justice - each will be handled according to law, without any restrictions.

- Equality - does not mean sameness, but a necessity based on specific needs, therefore equality of opportunity.

- Participation - involvement of clients, client involvement in selecting targets and resources.

Other authors, for example Denney (1983) distinguish the following types of antioppressive approaches:

- Assimilation - minority receives culture of majority, and surrenders most of its original culture in the process of acculturation.

- Liberal pluralism - the principle of equal opportunities are the result of anti-discrimination laws.

- Cultural pluralism - based on the possibility of coexistence of different cultures in the same place, the result is multiculturalism, currently very difficult approach.

- $\quad$ Structuralism - is based on the concept of social layers that have different access to power and resources, the result is either a confirmation of inequality or a fight for its settlement.

Neither of these approaches is ideal. Based on past experience, it is advisable to combine these approaches based on specific situations.

According to Navrátil (2013), Thompson introduces a concept of empowerment into antioppressive approach.

The author of the concept of empowerment, however, is not Thompson, but the Brazilian educator Freire. ${ }^{11}$ He devoted himself to improving the lives of the poor in the form of education. At the end of the 60s of the 20th century he comes with the work of Pedagogia del oprimido (Pedagogy of the Oppressed), which sees the individual as a self-forming entity that is aware of its historical development. Freire notes that oppressed groups based on various justifications of oppression perceive themselves negatively and feel unable to deal with the situation themselves (cf. Freire, 2001; Ledvinková \& Macků, 2011).

Navrátil (2013) in the analysis of Thompson's work Anti-discriminatory practice from 1997 states that Thompson replaces the concept of capacitation, which was normally used in social work, by authorization. Capacitation is a concept of adaptation, while authorization is a control over own life and living conditions. Correct application of antioppressive approach must be based on structural factors such as gender, identity and ethnicity, race, age, disability, sex or social orientation and their role in the life situations of people. To reflect these factors Thompson suggests P-C-S analysis, which means to assess the life situation of a specific person at a personal level - P (ideas, attitudes, feelings, actions), cultural - $\mathrm{C}$ (perception, thinking, behaviour), structural $-\mathrm{S}$ (social relationships). The result of this analysis is awareness that oppression and discrimination is not a matter of individuals but is based on cultural and social conditions. "Antioppressive model comes with initiatives to encourage social workers to reflect different aspects of the use of power and its impact on the life of the client" (Navrátil, 2013, p. 95).

In the current educational practice antioppressive approach is irreplaceable. It is preventing all forms of discrimination. It is used in everyday education. For being properly used by a teacher, he must be

11 Paulo Freire (1921-1997) a Brazilian educator, reformer, a Christian thinker, in our country known for the concept of critical thinking. 
able to work with prejudices, stereotypes and ethnocentrism. In working with different we often meet outminded and hard - to - realize prejudices. These are hard to control by individuals and in the mainstream society they are quite widespread, so you can expect that they also meet a teacher. Becoming aware of prejudices and stereotypes in attitudes and behaviour is the first way to antidiscrimination and application of the concept of $\mathrm{P}-\mathrm{C}-\mathrm{S}$ analysis. The second is to work with own ethnocentrism, that I can not assess culture of different people through the eyes of our culture.

A social educator should use the concept of empowerment in the intervention with socially excluded. It should encourage pupils or their parents to take responsibility and control over their lives, over their living conditions. The concept of empowerment also leads to self-acceptance, self-awareness, and that brings us to identity and ethnicity. Educator, as a guide empowerment expands students' social group that runs the culture of poverty, a broader community, transforms the feeling of belonging and perception of the concept we to more people, disrupts honored cultural patterns of culture of poverty, participates in forming a broader ethnicity, leading to assist integration and social inclusion.

The following two approaches are not direct methods of intervention in a specific sense. For the work of a social educator in working with a socially endangered child in socially excluded localities they are important.

One of these approaches is case management. Case management, sometimes a case social work - a case conference "is a coordinated action leading towards client support, with participation of all available sources (family, professionals, social and health services etc.). A professional is responsible for implementation of case management (usually a social worker) who is responsible for evaluating client's needs and together with the client and other people, who are interested in it, creates an individual plan" (Solařová, 2013, p. 4). It is a method that has not been considerably expanded in the Czech Republic so far. It is basically about contemporary classical case work, which is the basic approach of individual social work. Unlike traditional case work where one worker works with a client, the method of case management assumes more heads - more reason, therefore, of teamwork. Formation of multidisciplinary teams is so typical for case management that are currently used in working with socially excluded. The objective of this intervention is making a support network.

Knowledge of case management for a social educator is suitable for its understanding of the competencies of the multidisciplinary team members, for understanding the role of a coordinator and knowledge of support network formation. A social educator often becomes a coordinator, a case manager among students, school, family, volunteers providing tutoring, workers of social legal protection and curators. Knowledge of networking, namely, knowledge of networking and informal relationships among children, parents, siblings and people of the same age as well as assisting in the creation of non formal links and relationships among children, teachers, tutor, curator, etc., is essential for successful intervention. The result of this activity is an individual development plan, as it is in the Act No. 359/1999 Coll. (1999).

The second approach is a socio-ecological model or in literature sometimes referred to by the term ecological perspective. Social ecological model is based on the assumption of a man as a part of the ecosystem. It focuses on the individual in his environment, both social and natural, his relationship to this environment and interaction.

This approach appears in the 60s, when starting to develop the concepts of social functioning. An important personality was Gordon, who in 1969 came up with the idea for social work as the work between systems and environments. Thus ecological approaches are classified into system theory. Navrátil (2001) reports that Heard summarized Gordon's basic ideas of social work into seven points:

1. Social work has concurrently a dual perspective. It focuses both on man and his situation - that is, the system and its environment. 
Skarupská / Selected methods of intervention suitable for work social educator with children...

2. Social work takes place at the interface between the human system and its environment.

3. Phenomenon, which occurs at the interface between the system and the environment, is transaction.

4. Transaction is a process in which the system and its environment mutually attune. On the side of the system it is in terms of managing, and on the side of immediate environment it is in terms of its quality.

5. The interface of the system with the environment causes a change in both.

6. The best transactions are those that support the growth and development of a body while improving the environment (that means that it becomes a better place for all systems that depend on it).

7. For growth and development, it is essential that there is a persistent redistribution of entropy between the body and the environment.

Ecological approaches introduced additional terms into social work. The first is the adaptation, i.e., the ability to adapt to the social environment and the second resilience, or resistance, hardiness.

Tasks of social work in socio-ecological approaches lie in strengthening the competencies of clients in meeting their needs and the appropriate response to the demands of the environment in influencing social environment to allow meeting client needs and improving interactions between them and the social environment.

In the literature ${ }^{12}$ we meet definitions of three basic types of social functioning:

- Adaptive - adaptable, people have capacity to solve problems, working with them on a contract basis.

- $\quad$ Risk - do not have their own resources to deal with or are at risk of another system. Here it is necessary to use prevention, reduce hazardous systems.

- $\quad$ Maladaptive - problems are so serious that the systems are not able to solve them. Here it is necessary to use curative - protective activities of social work or social pedagogy.

Socio-ecological approaches do not focus only on the individual. Systems creating social support, which is kinship, neighborhood, local systems, but also social policy and social security systems. are getting In the foreground.

These approaches should be close to a social educator because he also is being educated in the field of environment. According to the type of environment he can chose appropriate types of interventions. In intervention at the level of the microsystem he is focused on the individual or his family where he tries to change. In intervention at the level of mezosystem he focuses on groups, eg. peers, class groups, and in intervention at a macro level he seeks to change the community, which includes a socially excluded locality.

Both these approaches - case management and social ecological model complete intervention methods. Possibilities of his position in a multidisciplinary team are presented to a social educator and especially lead him to work with an endangered child in socially excluded localities and be aware of the importance of the whole social environment and not to focus only on the child's personality.

\section{Conclusion}

In the presented study, I first dealt with the issue of defining differences and connections between a social worker and a social educator, defining phenomenon of the culture of poverty and

12 Cf. Bartlett (1970), Giddens (2013), Gordon (1969), Kraus and Poláčková et al. (2001). 
Skarupská / Selected methods of intervention suitable for work social educator with children...

consequently the possibility of appropriate interventions for endangered children from socially excluded localities. I am of the opinion that the social educator, is not a social worker, everyone has a different mission in solving social problems, although both are aimed the same target group. Social worker approaches to solving problems from social and psychological point of view, while social educator in terms of educational ones. Where the two professions can and should intermingle or supplement is the possibility of using approaches and methods that are used in both fields.

In this study I focus on a social educator who works in socially excluded localities. First of all, I describe the culture of poverty as a specific behaviour that is not still sufficiently known in the Czech professional public. Secondly, I am offering several approaches to a social educator that are applied in social work and are being recommended for work with this target group. My aim is thus to contribute to the expansion of professional competences of a social educator.

Selected methods of intervention can be used either independently or in combination with others. This is due to the complexity of the problems that occur in socially excluded localities. Social situation of a child is not only one social problem but affects the child, his personality, his education, socialization and its environment - family, school, work environment of parents, municipal environment, etc. For these reasons, the problem of a child is not possible to deal with without respect to the social situation of his family and community. Therefore, it is necessary to solve it comprehensively and precisely, for these reasons it is advisable to choose an eclectic approach. This approach gives us the possibility to choose among different methods of interaction, and variously combine and interconnect them. Thereby setting the intervention directly on the requirements of the endangered child and thus successfully operate and achieve the needed results.

As I explained in the third chapter, in the Czech Republic after the last crisis, the number of socially excluded localities increased and thus increased the population and children in these groups. In 2008 the government set up Agency for Social Inclusion to help socially excluded localities, however, it works on the principle of login, not on the principle of prevention and screening. Currently it only works with 26 sites, however, research of an agency GAC saw 606 of them for 2014.

If the state and government want to begin actively solve the situation of socially excluded localities in the future and thus children at risk of social exclusion, they will have to change the system of aid and especially in these localities to establish the position of social educator as a school worker in a socially excluded locality and thus a member of the multidisciplinary team. Then it is necessary that the social educator has to be well equipped for the job with knowledge of the problems of socially excluded groups, the specifics of culture of poverty and the different kinds of intervention, and especially could work with them.

\section{References}

Act No. 108/2006 Coll., on social services. (2006). Retrieved from http://www.zakonyprolidi.cz/cs/2006-108.

Act No. 359/1999 Coll., on social and legal protection of children. (1999). Retrieved from http://www.zakonyprolidi.cz/cs/1999-359

Act No. 563/2004 Coll., on pedagogical work. (2004). Retrieved from https://portal.gov.cz/app/zakony/zakon.jsp?page=0\&nr=563 2F2004\&rpp=15\#seznam.

Andrysová, P., \& Martincová, J. (Eds.). (2014). Profesní kontext sociální pedagogiky: Motivace studentů k výkonu. Zlín: Academia centrum.

Bakošová, Z. (2008). Sociálna pedagogika ako životná pomoc. Bratislava: Univerzita Komenského.

Barlett, H. (1970). The common base of social work practice. Washington: NASW Press. 
Skarupská / Selected methods of intervention suitable for work social educator with children...

Denney, D. (1983). Some dominant perspectives in the literature relating to multi-racial social work. British Journal of Social Work, 2(13), 149-174.

Dohnalová, M. (2011). Chudoba. In J. Malina (Ed.), Encyklopedie Antropologie. Brno: CERM. Retrieved from https://is.muni.cz/do/sci/UAntrBiol/el/encyklopedie/encyklopedie.html

European Union. (2001). Report on indicators in field of poverty and social exclusion. Brussels: European Commission.

Freire, P. (2001). Pedagogy of freedom. Blue Ridge Summit: Rowman \& Littlefield Publishers, inc.

GAC spol. s r.o. (2015). Analýza sociálně vyloučených lokalit v ČR. Praha: GAC.

Giddens, A. (2013). Sociologie. Praha: Argo

Gordon, W. E. (1969). Bacis constructs for an intergratice and generatice conception of social work. In H. Gordon (Ed.)., The general systems approach: Contributions toward and holistic conception od social work (pp. 5-11). New York: The Concil on Socila Work Education.

Grecmanová, H. (Ed.). (1996). Obecná pedagogika I a II. Olomouc: Hanex.

International Fedaration of Social Work (IFSW). (2015, July 30). Retrieved from http://ifsw.org/getinvolved/global-definition-of-social-work

Kraus, B. \& Poláčková V. (Eds.). (2001). Člověk - prostředí - výchova. Brno: Paido.

Kraus, B. (2008). Základy sociální pedagogiky. Praha: Portál.

Laca, S. (2011). Sociální pedagogika. Brno: IMS.

Ledvinková, M., \& Macků, R. (2011). Paulo Freire - pedagogika utlačovaných a její vztah k teologii osvobození. Caritas et veritas, 2(1), 68-78.

Levitas, R. A. (2003). The idea of social inclusion. In Social Inclusion Reseaech Conference (pp. 27-28). Kanata: Canadian Council on Social Development.

Lewis, O. (1966). The culture of poverty. American, 4(215), 19-25.

Mani, A., Mullainthan, S., Shafir, E., \& Zhao, J. (2013). Poverty impedes cognitive function. Science, 341(976), 976-980. doi:10.1126/science.1238041

Mareš, P. (2006). Faktory sociálního vyloučení. Brno: VÚPSV.

Ministry of Interior of the Czech Republic (MVCR). (2015, November 10). Indicative number of people in the Czech Republic in all municipalities, communities and the third type in urban areas. Retrieved from http://www.mvcr.cz/clanek/statistiky-pocty-obyvatel-v-obcich.aspx

Ministry of Labour and Social Affairs (2009a, December 5). Proposed measures to transform and unify the system of care for endangered children - basic principles. (pp. 1-9). Retrieved from http://www.mpsv.cz/files/clanky/9556/Navrh_opatreni_k_transformaci.pdf

Ministry of Labour and Social Affairs (2009b, December 5). The National Action Plan to transform and unify the system of care for endangered children for the period from 2009 to 2011 až 2011. (pp. 1-21). Retrieved from http://www.mpsv.cz/files/clanky/7440/NAP.pdf

Murray, Ch. (1998). Přiliš mnoho dobra. Praha: Slon.

Navrátil, P. (2001). Teorie a metody sociální práce. Brno: Marek Zeman.

Navrátil, P. (2007). Vybrané teorie sociální práce. In O. Matouček (Ed.), Základy sociální práce (pp. 183-261). Praha: Portál.

Navrátil, P. (2013). Antiopresivní př́stup. In O. Matoušek (Ed.), Encyklopedie sociální práce (pp. 9295). Praha: Portál. 
Skarupská / Selected methods of intervention suitable for work social educator with children...

Navrátil, P., \& Matoušek, O. (2013). Úkolově orientovaný př́stup. In O. Matoušek (Ed.), Encyklopedie sociální práce (pp. 109-113). Praha: Portál.

Novotná, V., \& Schimmerlingová, V. (1992). Sociální práce, její vývoj a metodické postupy. Praha: UK.

Smelser, N., \& Baltes, B. (2001). Internacional encyklopedia of the social \& behavioral sciences. Oxford: Elsevier Science Ltd.

Solařová, H. (2013). Case management aneb případové konference v praxi. Pardubice: Benepal.

Thomas, M., \& Pierson, J. (1995). Dictionary of social work. London: Collins Educational.

Thompson, N. (1992). Existentialism and social work. Aldershot: Avebury.

Toušek, L. (2007). Sociální vyloučení a prostorová segregace. AntropoWebzin, 2-3, 12-24.

William Glasser Institute (2015, April 15). Reality therapy. Retrieved from http://www.wglasser.com

World declaration on the survival, protection and development of children (1990, September 30). Retrieved from http://www.unicef.org/wsc/declare.htm

Zakouriilová, E. (2014). Speciální techniky sociální terapie rodin. Praha: Portál. 